\title{
The Sustainability of GCC Development Under the New Global Oil Order
}

\author{
Ibrabim A. Elbadawi and Samir Makdisi
}

\section{INTRODUCTION}

The six-member countries of the Gulf Cooperation Council (GCC) have been able to sustain fast growth for over 30 years, since the start of the oil price boom of the mid-1970s. Though growth has of course been volatile, following the various oil cycles, it continued to rise or remained stable at high rates throughout the period. And, some GCC countries, such as the UAE, and most notably the sub-economy of the Emirate of Dubai, have managed to achieve tremendous economic transformations towards more diversified and sophisticated economic structures. Moreover, the GCC monarchies have been able to avoid civil wars and maintain civil peace.

The authors would like to acknowledge the helpful comments of Layal Mansour on an earlier draft.

I. A. Elbadawi

Economic Research Forum, Cairo, Egypt

S. Makdisi $(\bowtie)$

The American University of Beirut, Beirut, Lebanon

(C) The Author(s) 2021

G. Luciani, T. Moerenhout (eds.), When Can Oil Economies Be

Deemed Sustainable?, The Political Economy of the Middle East, https://doi.org/10.1007/978-981-15-5728-6_13 
They have also presided over a somewhat functioning social contract that helped them to fend off the fallout from the Arab Spring, which swept several major countries in their neighborhood.

At the other extreme, the populous oil Arab economies ${ }^{1}$ have experienced the "resource curse" big time: a disappointing growth record, limited economic diversification, depleted physical and soft infrastructures, massive unemployment, especially among youth, and political instability, even civil wars.

And in terms of policies and economic institutions, the contrast of the two groups is equally stark (Elbadawi et al. 2017). The GCC countries have been able to maintain macroeconomic stability through a credible de facto institutional exchange rate peg regime, supported by massive foreign account surpluses in the form of reserves accumulation and sovereign wealth funds (SWFs). Moreover, the deep fiscal pockets of the GCC countries allow fiscal stabilization against the oil market shocks, most notably ensuring uninterrupted large fiscal outlays for financing infrastructure development and other social sector programs as well as expansion of public sector employment for nationals. Also, their open trade, capital accounts and labor market policies provided a good measure of macroeconomic competitiveness to the GCC economies, hence moderating the adverse consequences of the rigidity of the exchange rate regime. By contrast, the populous oil Arab economies have been plagued by intermittent bouts of inflationary spells, overvalued real exchange rates and fiscal dominance and less buoyant growth.

The received literature suggests that the "resource curse" is a long-term phenomenon but is conditional on poor political governance. Empirical evidence shows that in resource economies lacking political inclusiveness and effective "checks and balances" institutions, resource rents are likely to be a hindrance rather than a boon to growth. Moreover, resource rents tend to have corrosive effects on the quality of economic and political institutions (e.g. Collier and Goderis 2009; Elbadawi and Soto 2012a). Also, the evidence from the empirical strand of the civil war literature finds that, in the absence of political inclusiveness and accountability, the

\footnotetext{
${ }^{1}$ Though Saudi Arabia is relatively populous, in terms of rents per capita, it is more comparable to the high rents per capita GCC countries of Kuwait, Qatar and UAE than the other populous oil Arab economies of Algeria, Iraq and Yemen. As discussed in the literature, rents per capita above a certain threshold have been a major factor in explaining the superior performance of the GCC economies relative to the populous oil Arab economies (e.g. Ali and Elbadawi 2012; Elbadawi 2016).
} 
presence of resource rents increases the risks of conflicts for both "loot" and "grievance" motives (e.g. Collier and Hoeffler 2004; Bodea and Elbadawi 2007).

However, while the literature seems to adequately account for the poor management experiences of the populous oil Arab economies and most other resource-abundant countries, it seems to provide little predictive power for the case of the GCC. In fact, Elbadawi (2016) has shown that there is a small group of 12 exorbitantly high oil rent per capita countries that are mostly non-democratic (hereafter HRPC), including the GCC, which seem to defy the fundamental tenets of the received literature that non-democratic governance affects growth negatively. He finds that there exists a resource rents threshold, beyond which countries might be able to achieve fast growth and civil peace as well as avoid revolt regardless of the prevailing standard in terms of accountable political institutions. This finding lends support to theory suggesting that high-enough resource rents per capita could lead to a developmental, if non-democratic, political equilibrium (Ali and Elbadawi 2012).

This chapter reviews the development experiences of the GCC countries in the context of three development goals: growth, civil peace and political stability; it undertakes a synthesis of the literature, largely drawing from the authors' own work. However, the main contribution of the chapter relates to identifying the prospects for the sustainability of the GCC development model in the emerging new "global oil order", expected to eventually lead to a low oil price "equilibrium" in the longer run.

Section 2 reviews the received literature on the causal links from rents per capita to growth, especially the evidence on the existence of nonmonotonic growth effects. Section 3 reviews the literature on the scalecontingent role of resource rents as a determinant of conflicts and democratic transitions. In this context, it discusses the significance of threshold effects in explaining the apparent success of the GCC monarchies in avoiding civil wars as well as pre-empting potential revolts. Section 4 , which is the hallmark of this paper, asks the pivotal question as to the sustainability of the GCC development model in the emerging new global oil order. Section 5 concludes. 


\section{Growth and Institutions in the GCC: Resource Rents Threshold MatTers}

As discussed, the received literature suggests that resource-abundant ${ }^{2}$ economies tend to grow slowly and that such countries are likely to be impacted by the "resource curse", with only few exceptional cases of countries that happen to be endowed with robust political and economic institutions (e.g. Collier and Goderis 2009; Elbadawi and Soto 2012a). However, though this literature has been borne out by the experiences of most resource-abundant countries, the six GCC countries seem to have defied this empirical finding. They have been able to grow rapidly over the longer term, despite their entrenched non-democratic governance.

We argue that the level of resource abundance, as measured by resource rents per capita, is central to explaining the superior growth performance of the GCC, compared to other less endowed populous oil and mineral economies. The distribution of countries by this criterion reveals considerable heterogeneity. For the period 2000-2013, the median rents per capita for the HRPC group (comprising countries with rent per capita in excess of $\$ 2000$ ) was $\$ 5322$, more than eight times the median for the second most resource-abundant group of 15 countries, whose rents per capita are within the range of $\$ 400$ to $\$ 2000$ (Table 13.1). In view of their vast hydrocarbon resource base and relatively small populations, it is not surprising that the high resource-endowed GCC countries have dominated the list of the top ten countries in terms of rents per capita. It is, however, notable that they also dominated the top ten fastest growing countries during the last three decades (Figs. 13.1 and 13.2). By comparison, the populous oil Arab economies, among other resource economies, achieved much lower growth rates.

The comparative growth experiences of the GCC and other less resource-abundant countries suggest the existence of association, not necessarily causation, between unusually high rents per capita and long-term growth. Moreover, governance data also reveal that the median country from the HRPC group, including the GCC, receives the lowest scores in two global political governance indicators: Polity2, the widely accepted

\footnotetext{
${ }^{2}$ Throughout this paper, we use the concept of "resource abundance" (measured by resource rents per capita), as opposed to the alternative concept of "resource dependency", which is given by rents/GDP. The latter has been criticized in the empirical growth and conflict literature, due to reverse causation (Elbadawi and Soto 2012a; Ross 2004, 2009).
} 
Table 13.1 Typology of resource rents per capita (average: 2000-2013)

\begin{tabular}{|c|c|c|c|c|}
\hline $\begin{array}{l}\text { Resource rents per } \\
\text { capita }\end{array}$ & Median & Min & $\operatorname{Max}$ & $\begin{array}{l}\text { Number of } \\
\text { countries }\end{array}$ \\
\hline $\begin{array}{l}\text { Rents } P c<20 \\
\text { USD }\end{array}$ & 9 & $\begin{array}{l}\text { Iceland (0.06 USD/ } \\
\text { capita) }\end{array}$ & $\begin{array}{l}\text { Cambodia (20 USD/ } \\
\text { capita) }\end{array}$ & 46 \\
\hline $\begin{array}{l}20<\text { Rents } \\
\mathrm{Pc}<200\end{array}$ & 47 & $\begin{array}{l}\text { Switzerland ( } 20.01 \\
\text { USD/capita) }\end{array}$ & $\begin{array}{l}\text { Bhutan (189 USD/ } \\
\text { capita) }\end{array}$ & 88 \\
\hline $\begin{array}{l}200<\text { Rents } \\
\text { Pc }<400\end{array}$ & 294 & $\begin{array}{l}\text { Brazil (200 USD/ } \\
\text { capita) }\end{array}$ & $\begin{array}{l}\text { United Kingdom } \\
\text { (398.5 USD/capita) }\end{array}$ & 16 \\
\hline $\begin{array}{l}400<\text { Rents } \\
\mathrm{Pc}<2000\end{array}$ & 616 & $\begin{array}{l}\text { United States ( } 409 \\
\text { USD/capita) }\end{array}$ & $\begin{array}{l}\text { Venezuela, RB } \\
\text { (1424.3 USD/capita) }\end{array}$ & 15 \\
\hline $\begin{array}{l}\text { Rents Pc }>2000 \\
\text { USD }\end{array}$ & 5322 & $\begin{array}{l}\text { Gabon (2326 USD/ } \\
\text { capita) }\end{array}$ & $\begin{array}{l}\text { Qatar (70,537 USD/ } \\
\text { capita) }\end{array}$ & 12 \\
\hline
\end{tabular}

Source: Elbadawi (2016)

Notes: (1) Total natural resources rents are the sum of oil rents, natural gas rents, coal rents (hard and soft), mineral rents and forest rents. (2) For the GCC, resource rents per capita were computed as a ratio of total rents to national population, where the latter was calculated using $49 \%$ in Bahrain, $68 \%$ for Saudi Arabia, $61 \%$ for Oman, $16 \%$ for the UAE, 32\% for Kuwait and 16\% for Qatar

measure of political inclusiveness; and Polcon, a new index of the effectiveness of political constraints on the executive and legislative branches of government $^{3}$ (Fig. 13.3).

At the same time, looking at the HRPC group, and specifically the GCC, their record of avoiding civil wars and maintaining stability is impressive. It stands in contrast to that of other resource-dependent

${ }^{3}$ The Polity 2 is a global database developed by the "Polity IV: Regime Authority Characteristics and Transitions Datasets" project; and the Political Constraint Index (POLCON-V) is also a global index due to Henisz and Zelner (2010).

It is not surprising that most country groups, especially the HRPC, received low scores on both indices (Fig. 13.3). A more detailed country-specific analysis of the two indexes suggests that the Polity 2 index (rescaled so that 1 stands for full democracy, and 0 stands for extreme autocracy) for the median political regime in the three country groups with rents less than $\$ 400$ is likely to be "partial democracy". Instead, for the group with rents less than 2000 but higher than $\$ 400$, which includes the populous oil economies of Algeria and Iran, it is likely to be an "autocracy"; and except for Norway and Trinidad and Tobago, the rest of the countries in the highest resource-abundant group are all judged to be extreme autocracies. Furthermore, the resource-rich countries tend to fare much worse according to the Polcon, with the median index below 0.4 for all groups, which suggests weak systems of political checks and balances. Again, except for the two democracies of Norway and Trinidad and Tobago, the Polcon index for the HRPC group is close to zero, suggesting that a system of "formal" checks and balances does not even exist in these countries (Elbadawi 2016). 
Real Average Economic Growth Rate per capita (1985 to 2016)

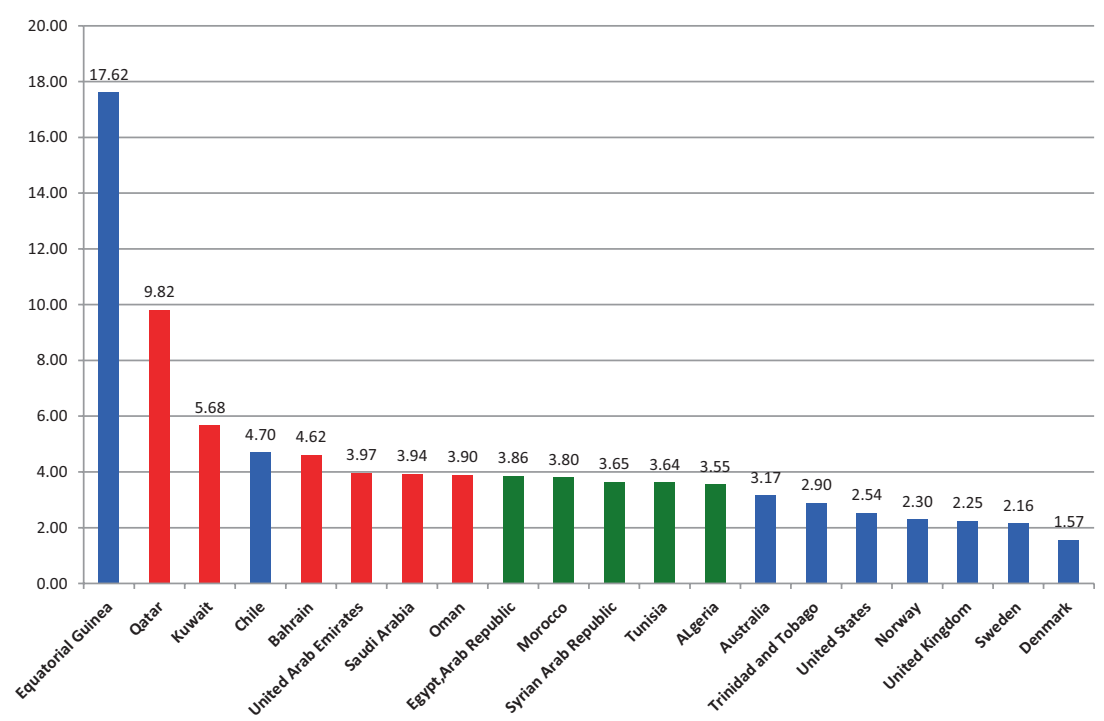

Fig. 13.1 Average rent per capita (2000 to 2016). (Source: World BankInternational Financial Statistics (IFS) and authors' own elaboration. Notes: (1) Total natural resources rents are the sum of oil rents, natural gas rents, coal rents (hard and soft), mineral rents and forest rents. (2) National population for GCC countries are taken from Gulf Labor Markets, Migration and population (GLLM) programme (https://gulfmigration.org/glmm-database/) since national population represents a very small portion of the total population)

countries [populous?] which have been impacted by frequent and

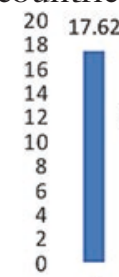

9.82

5.68

4.704 .623 .973 .943 .903 .863 .803 .653 .643 .553 .172 .90

2.542 .302 .252 .161 .57

$a^{20^{2}}$

Fig. 13.2 Real average economic growth rate per capita (1985 to 2016). (Source: World Bank-IFS Data and authors' elaboration) 


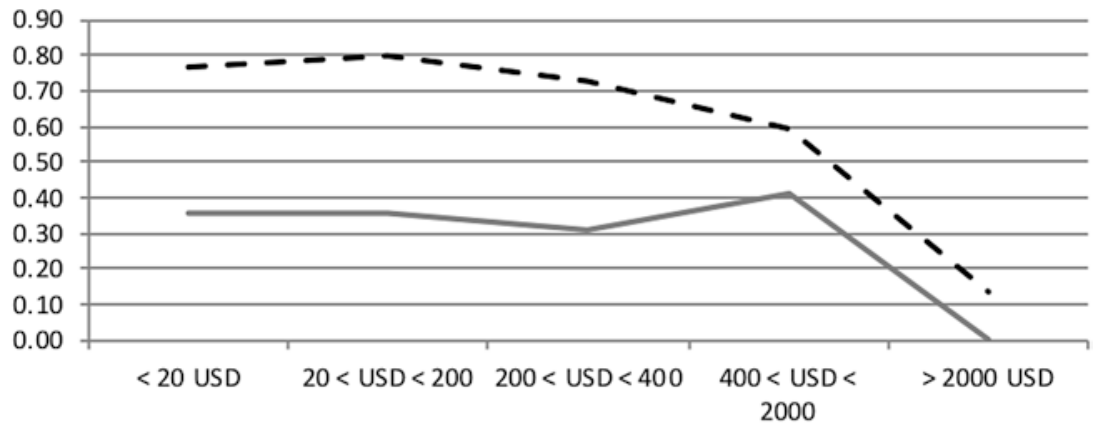

- - Median Polity Median Political Contraints

Fig. 13.3 Median average polity and political constrains in resource-rich economies. (Source: Table 10.3 of Elbadawi 2016)

Table 13.2 Armed civil conflicts, 1970-2010

\begin{tabular}{lcc}
\hline Resource rents per capita & Number of countries & Longest war duration \\
\hline Rents $\mathrm{Pc}<20$ USD & 10 & 41 years \\
$20<$ Rents $\mathrm{Pc}<200$ & 36 & 41 years \\
$200<$ Rents $\mathrm{Pc}<400$ & 4 & 41 years \\
$400<$ Rents $\mathrm{Pc}<2000$ & 7 & 26 years \\
Rents $\mathrm{Pc}>2000$ USD & 2 & 1 year \\
\hline
\end{tabular}

Source: Table 10.2 of Elbadawi (2016)

long-duration conflicts (Table 13.2). Similarly, the long-reigning GCC monarchies have not only been able to maintain domestic political stability, but to avoid, so far at least, the contagion effects of the Arab Spring (Table 13.3). While it is not surprising for full democracies, such as Norway and Trinidad and Tobago, to enjoy political stability, this has been a challenging goal for authoritarian elites in relatively limited resourceabundant societies (Elbadawi 2016). The explanation, as discussed later, relates to the role played by relatively abundant resource rents.

The aforementioned evidence naturally motivates the question as to whether unusually high resource abundance (such as that of the GCC and other countries in the HRPC group) is likely to promote growth regardless of the quality of the underlying political institutions. This question was addressed by Elbadawi (2016), who, firstly, estimates a baseline 
Table 13.3 Political regimes types and years in power

\begin{tabular}{llll}
\hline Country & Duration and regime type & \\
\hline Rents per capita $>\$ 2000$ & & & \\
Kuwait & 1962 & Present & Monarchy \\
Saudi Arabia & 1928 & Present & Monarchy \\
Oman & 1742 & Present & Monarchy \\
UAE & 1972 & Present & Monarchy \\
Bahrain & 1971 & Present & Constitutional monarchy \\
Qatar & 1971 & Present & Monarchy \\
Brunei & 1984 & Present & Constitutional monarchy \\
Norway & 1886 & Present & Democracy \\
Trinidad and Tobago & 1962 & Present & Democracy \\
Gabon & 1961 & Present & Party-personal \\
Equatorial Guinea & 1968 & Present & Personal-military \\
Equatorial Guinea & 1979 & 1978 & Personal-military \\
Libya & 1952 & 1969 & Monarchy \\
Libya & 1970 & 2010 & Personal \\
\hline
\end{tabular}

Source: Table 10.3 of Elbadawi (2016)

growth model that accounts for the level resource rents per capita and its squared value as well as other standard growth fundamentals other than political governance institutions. He finds that there exists a statistically significant but non-monotonic resource-abundance effect on growth, where resource abundance constitutes a hindrance to growth for countries with rents per capita lower than $\$ 1800$, while those on the higher side of the tipping level should be able to unconditionally turn the resource rents into positive growth regardless of the quality of the underlying institutions. In view of such exorbitantly high threshold, only the HRPC group, especially the GCC, qualifies for such type of the growth process. In the extended model that also accounts for economic and political institutions, Elbadawi estimates a much lower tipping point at $\$ 148$ when he controls for both Polity and Polcon. These results suggest that, conditional on good political governance, societies with moderate to high rents per capita (currently about 51 ) should be able to realize positive conditional growth from their resource endowments.

However, though the tipping point of the rent per capita was significantly reduced after controlling for the two indicators of political governance, the effect of rents remains. This suggests that whatever the GCC political construct, growth performance of the region has been anchored 
by their unusually high rents per capita, and that the ensuing growthpromoting political equilibrium has not been explicable in terms of the two global political indicators.

\section{Maintaining Civil Peace and Political Stability: Resource Rents Threshold also Matters}

Looking at the HRPC group, and specifically the GCC, noteworthy is their record of avoiding civil wars and maintaining stability. It stands in contrast to that of other resource-dependent countries [populous?] which have been impacted by frequent and long-duration conflicts (Table 13.2). Similarly, the long-reigning GCC monarchies have not only been able to maintain domestic political stability but to avoid, so far at least, the contagion effects of the Arab Spring (Table 13.3). While it is not surprising for full democracies, such as Norway and Trinidad and Tobago, to enjoy political stability, this has been a challenging goal for authoritarian elites in relatively limited resource-abundant societies (Elbadawi 2016). The explanation, as discussed later, relates to the role played by relatively abundant resource rents.

\subsection{Resource Rents, Threshold Effects and Civil Wars}

Like growth collapse, civil wars have been prominently analyzed in the economic and political science literature as a major manifestation of the resource curse. ${ }^{4}$ It has been argued that the existence of a "lootable" resource base is both a motive for rebellion and a facilitating factor. Because they need to purchase arms and recruit fighters, rebel organizations cannot survive without access to natural resource rents or other sources of easy financing, such as financial and military aid from sympathetic diaspora or friendly governments. For example, in Collier and Hoeffler (2004), the equilibrium level of the risk of conflict is given by equating the marginal product of rebel labor and government strength (measured by the economic strength and the size of the military) to their respective marginal costs for a given level of natural resources. This

\footnotetext{
${ }^{4}$ See, for example, Collier and Hoeffler (2004), Fearon (2005), Miguel et al. 2004), Sambanis (2004), Bodea and Elbadawi (2007), Caselli and Coleman (2013) and Elbadawi and Soto (2015), as representative examples on natural resource and conflicts.
} 
framework solves for the risk of civil war onset as increasing with the natural resource endowment and decreasing with the opportunity cost of rebellion.

Again, though the linear effect of resource rents on the hazard of conflicts seems to account for the experiences of many, if not most resourceendowed countries, it does not, however, cohere with the evidence from the HRPC group, especially the GCC. As argued by Elbadawi (2016), "very high resource rents might in fact be a deterrent to conflict, either through the 'Hobbesian' effect of providing the state with substantial resources to crush potential insurgency or through strengthening the 'authoritarian bargain', which proved to be effective in preempting incipient conflicts in highly resource endowed societies". Subscribing to this argument, he estimates a model to test for the marginal effect of the resource per capita for HRPC group, which is given by an interactive term between rents per capita and the dummy for the HRPC group. In addition to the level effect of the rents per capita and the two political institutional variables, the model also accounts for the standard controls in this literature, including income per capita and population size.

As in the received literature, the overall linear rents effect remains positive and highly significant, but the threshold effect was negative and highly significant as well. This suggests that the HRPC group was able to substantially ameliorate the risk of civil war associated with resource rents. Moreover, marginally expanding the threshold to include the 15 countries in the following group (with rents per capita higher than $\$ 400$ but lower than \$2000) renders the threshold effect insignificant. As for the two political institutions, political checks and balances were found to be robustly and negatively associated with the hazard of civil war. Moreover, checks and balances appear to have weakened the linear rents effect, which was reduced in terms of order of magnitude and degree of significance when the former is included in the regression. Instead, and contrary to the model's prediction, democracy was not found to exert any significant influence.

\subsection{Resource Abundance, Threshold Effects and Democratic Transitions}

Until recently, the Arab world has been immune to the various democracy waves that swept the developing countries since the end of WWII. This prompted some scholars to claim that Arab societies are culturally 
different, attributing lagging Arab democratic development to the socalled neo-patriarchy thesis. However, the popular uprising that swept the Arab world since 2010 suggests this is not what explains "Arab exceptionalism" to democracy. An alternative thesis for explaining the limited democratization in the Arab world is provided by Elbadawi and Makdisi (2011, 2017) and Elbadawi et al. (2011), who argue that, along with conflicts, the dominance of the hydrocarbon resource on Arab economies appears to be the main culprit, because it allowed incumbent autocrats to build a much more durable "authoritarian bargain" than has been possible in less resource-dependent regions.

However, again the resource rents as instrument for "greasing" the authoritarian bargain are not likely to have a linear effect. This is why several incumbent regimes in the oil-rich but populous Arab countries have experienced repeated revolts, coups and, more recently, mass protests, while the GCC monarchies remain fairly safe. This points to the limits to the effectiveness of the authoritarian bargain for the former; hence, suggesting that the role of resource rents as a hindrance to democratic transition might be subject to scale effects, akin to the cases of growth and civil peace.

Ali and Elbadawi (2012) develop a game-theoretic political economy model that accounts for two strategies that might be adopted by an incumbent autocrat to avoid or prevent a revolt by the citizenry (see also Desai et al. 2009; Esfahani and Gurakar 2014; Hodler 2006; Robinson et al. 2006). They show that there exists a threshold of rent per capita, above which the dominant strategy will be to spend on public employment and other public goods. Instead, for those less-endowed societies (i.e. below the threshold), elites will primarily rely on political repression as the main strategy for holding on to power. The predictions of this model are strongly corroborated by the evidence provided by Elbadawi (2016). ${ }^{5}$ Indeed, the HRPC group seems to rely much less on political repression than does the median country in the rest of the resource countries. Furthermore, the former, especially the GCC countries, spend much more

\footnotetext{
${ }^{5}$ The evidence provided by Elbadawi (2016) is based on a direct measure of government repression that is available in the recently developed Cingranelli-Richards data set (2008). This measure, called Physical Integrity Rights, constructs an annual variable that ranges from 0 (worst repression) to 8 (repression free) and accounts for the incidence of torture, extrajudicial killing, political imprisonment and disappearances that are attributable to the government.
} 
(on per capita basis) on education and health as well as building vastly superior infrastructure.

To assess the effectiveness of the two alternative strategies in preventing a revolt, Elbadawi and Makdisi (2013) estimate an extended version of the modernization democratic transition model that accounts for the potential role of resource rents per capita and political repression as hindrances to democratic transition. In addition to the standard modernization controls, such as income per capita and economic growth, their model also accounts for the effects of home wars, unemployment and the legacy of previous political instability, given by the number of times a country experienced a transition from democracy to autocracy.

They find that political repression, like unemployment, seems to fully explain the resource rents effect as a hindrance to democracy in low or moderate rents per capita group, such as the populous oil Arab economies. However, it does not fully account for the resource effect for the highly endowed group, most notably the GCC. Drawing on the implications of these findings, the two authors interpret their findings as corroborating the predictions of Ali and Elbadawi's model, that is, in high-resource but population-scarce countries, the elites are likely to rely more on expanding public employment and less on political repression. Instead, the opposite is likely to happen in moderately endowed but populous countries.

\section{GCC Development Sustainability: Some Challenges Ahead}

No doubt the GCC had a very strong growth record (Fig. 13.2). However, growth has been largely driven by factor accumulation in the form of massive investments and even more through large-scale utilization of unskilled and semi-skilled labor, mainly drawn from the Indian subcontinent. This growth model has obviously served the GCC well and allowed the building of state-of-the-art infrastructure at exceptionally low cost of labor. But one major drawback of the GCC growth strategy has been low and even declining total factor as well as labor productivity. This feature of the growth process raises serious doubts about the sustainability of growth, indeed of the entire GCC development model. Probing deeper into this issue, let us consider the case of the UAE, the second largest economy in the GCC and the Arab world. The economy of the UAE, most notably that of the Emirate of Dubai, has achieved the most significant 
transformation. In about 35 years (from 1975 to 2010), the country's output multiplied by five times (in real PPP prices), with an annual average growth rate for the period at $5.4 \%$. However, though this growth was among the highest in the world, it has been associated with disappointing productivity growth rates.

The local economy of Dubai, the poster child of economic diversifying growth in the entire region, provides even more impressive economic development experience. The Emirate's economy has multiplied by 11 times during roughly the same period (1975-2008), growing by an exceptional nine percent per annum during the last 15 years of that period (Elbadawi and Soto 2012b). Nonetheless, despite its exceptionally commendable growth and much deeper economic transformation, Dubai has not been able to distinguish itself in terms of productivity growth. In fact, both average labor and total factor productivities remained stagnant for a long period of time (1987-2008 $)$ following the substantial decline in the early 1980s. This contrasts sharply with the other city-states, where average labor productivity has grown steadily with time (Fig. 13.4).

It has been argued that the prevailing social contract in the GCC, which essentially underpins the political settlement for resource mobilization and distribution in these societies, is not capable of generating high productivity growth, even in the most successful growth model of the UAE, and especially Dubai. In the context of this social contract, nationals are provided assured public employment at high-enough wages reflecting their wage reservation levels as wealthy societies, while granting the private sector a privileged access to an unlimited supply of unskilled foreign labor. The public sector commitment to meet the demand for employment by nationals provides strong incentives, for entrepreneurs prefer to employ labor-intensive rather than more sophisticated and high productivity production techniques.

One frequently cited reason is the so-called kafala system, "which provides significant market power derived from the fact that an employee is forbidden to change occupations while the contract is in force and is required to leave the country upon expiration. This absence of horizontal mobility allows employers to extract economic rents: when choosing production technologies, therefore, employers would tend to focus on labor intensive techniques that, in addition to the normal profit obtained from

\footnotetext{
${ }^{6}$ This trend will likely to have continued following the post-2008 global economic recession.
} 


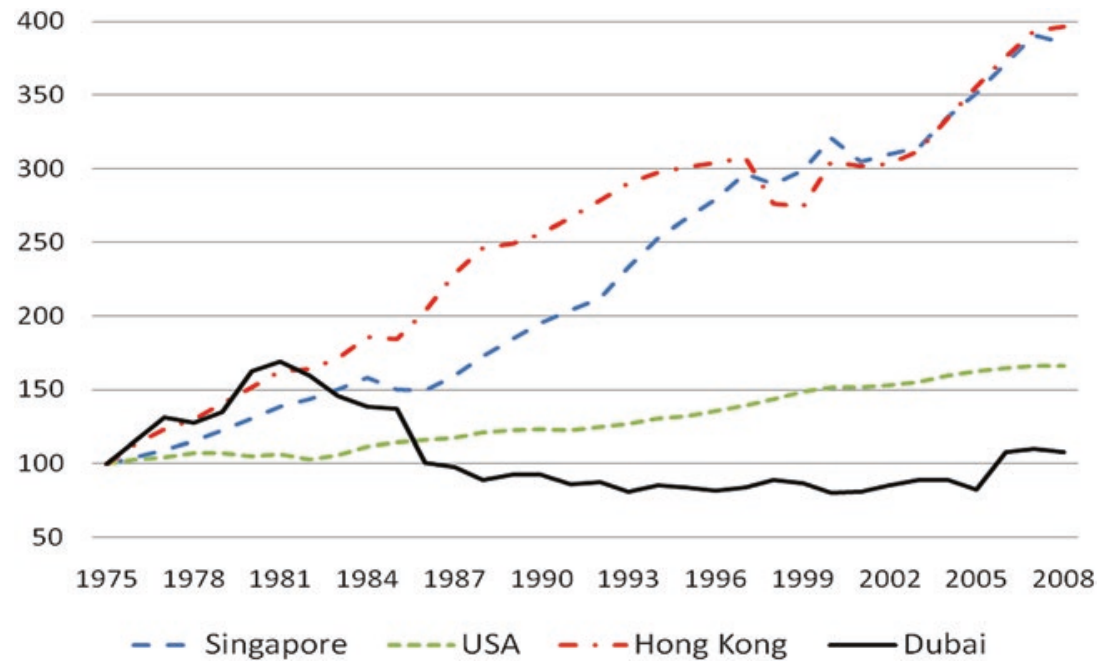

Fig. 13.4 Real GDP per working-age person $(2000=100)$. (Source: Elbadawi and Soto 2012b)

selling goods, would allow them to extract the highest rents from the worker. Naturally, this skews production towards labor-intensive technologies. It also biases employment toward low-skilled workers that have less ability to negotiate salaries in contrast with highly skilled workers are better educated and scarcer and, thus, better equipped to counterbalance the market power of employers. This aspect of the kafala would explain why labor productivity in the UAE is lower than in countries with similar GDP per capita" (Soto and Haouas 2012). However, even without the kafala system, the free access to the essentially unlimited supply of labor in the nearby southern Asian labor markets, coupled with large-scale publicsector contracts for entrepreneurs and developers in the construction and real estate sectors, would probably constitute a sufficient reason to steer their preferences toward the prevailing low-productivity model.

The 2008 global economic crisis and its aftermath have served a wakeup call to governments and societies at large about the need to reconsider the growth model and its underlying social contract. It is now a widely held view, by academic researchers and business experts alike, that eventually the price of oil will be converging to lower long-term trend, driven by the accelerating pace of technological advances in renewable energy as well as 
the shale oil and gas energy sources (Arezki and Matsumoto 2018). This realization has been borne out in the recent development strategies announced by GGC governments, all of which aimed at achieving transition to high-productivity, knowledge-based economies. Naturally, under the new oil order, such a transition is unavoidable, where these countries could no longer afford to use their deep fiscal pockets (e.g. reserves and SWFs) to finance expanding budgets or to maintain the credibility of their fixed exchange rate regimes. Moreover, guaranteed public sector employment of nationals is no longer possible in a few GCC countries, and major reforms to end the labor market segmentation will be required. However, the most difficult part of the new emerging GCC development agenda would be the realignment of political governance so as to allow for the required labor market and other public sector policy reforms.

At this juncture, perhaps the most compelling question to ask with regard to development sustainability of the GCC countries would be the following: In which direction might the political equilibrium in these societies shift as a consequence of the new global oil order?

To address this pivotal question, we consider the received institutional economics literature on the processes of formation and transition of economic and political systems in a society (e.g. North et al. 2009; Acemoglu 2008). According to this literature, a society is governed by a "limited access orders" (LAOs), when a relatively small but cohesive group of elites manage to exercise monopoly over the projection of organized violence and are able to restrict access to economic and political power. The elites, therefore, will tend to deploy the coercive power of the state in order to extract rents from the rest of the society. Furthermore, the restricted access to rents provides an incentive to the ruling elites to favor cooperation with each other and avoid or reduce violence against the population. An LAO might get trapped into a "fragile" state, when the ruling elites cannot agree on a formula for rents distribution due to the shifting balance of power among the various players. Instead, should the balance of power allow elite factions to establish a stable and predictable, if inter-personal, formula for distributing rents, the system becomes a "mature" limited access order (LAO). In this case, the elites have vested interest to invest and have the economy grow. However, even under mature LAOs, growth is not likely to be sustainable due to the marginalization of most of the population. Moreover, depending on external factors and internal developments alike, mature LAOs could very well collapse into a violent fragile 
state or, alternatively, graduate into an impersonal open access order $(\mathrm{OAO}){ }^{7}$

OAOs are built around impersonal rules that are broadly accepted by the society, and hence are self-reinforcing and not subject to ad hoc changes. These rules, or social contracts, must ensure open access as well as full accountability of those in positions of power to the general public. As articulated by Esfahani and Gurakar (2014), "The constraint on changes in the key rules under OAO is the cost of coordination and consensus building across large numbers of individuals and organizations. As a result, those who are elected to lead the state apparatus face constraints in getting other actors to help them change the rules in their favor, particularly because the other actors expect everyone else to hold them responsible if they deviate from the rules. Openness of access to political and economic leadership positions further means that those who are put in charge of political offices are replaceable by other contenders. So, they cannot expect to have much leverage over other members of the society to establish their own personal fiefdoms within the state. This in particular implies that the armed forces as state organizations cannot use the means at their disposal to violently gain direct or indirect control over the government. Rather, the military and security forces are placed under the consolidated control of civilians who represent the public" (p. 6).

Subscribing to the aforementioned conceptual framework, the prevailing GCC politico-economic institutional setup might be described as a relatively advanced form of "limited access order" (LAO), where projection of organized violence is firmly under the incumbent authorities and rents distribution is governed by inter-personal networks, but at the same time adjudication and settlement of disputes among the elites become increasingly formalized through courts and other formal arrangements. It follows that the prospects of significantly lower oil prices under the new global oil order, and the ensuing reductions in rents per capita, might very well push the GCC political equilibrium from an advanced LAO to a fragile state of LAO, akin to the one that prevails in some of the populous Arab oil countries. Such unfortunate transition would surely put an end to the GCC's relatively successful development model. On the other hand, it is possible that the path dependence of the political process in some at least of the GCC member countries might create some positive inertia,

${ }^{7}$ For example, Esfahani and Gurakar (2014) analyze the interplay of these factors in shaping the contrasting path from LAOs for the cases of Iran and Turkey. 
leading them to develop into an impersonal "open access order" (OAO), whereby the society graduates to a stable institutional equilibrium.

\section{Concluding Remarks}

Thanks to relatively abundant resource rents, as measured by resource rents per capita above a specified threshold, the GCC countries have been able, thus far, not only to avoid the negative politico-economic consequences of the oil curse but also to generally maintain high rates of economic growth along with political stability. However, with the expected future persistence of a lower oil price equilibrium along with growing popular demands in the region for political change in the direction of democratic governance - whatever the outcome, so far, of the Arab uprisings of 2011 - great challenges face the GCC countries.

Accordingly, we would argue, the stability of the prevailing "mature" LAOs that seem to characterize the economic and political order in the GCC will be seriously challenged by the prospects of lower oil prices in the future, along with other emerging regional and domestic developments, such as the youth bulge and the rising regional tensions and continuing civil wars and conflicts in the neighboring countries.

Thinking ahead, the fundamental question that would need to be addressed, in separate research, is whether or not the GCC countries are capable of initiating the required change in their political and economic model. And in either case, what would be the consequent politicoeconomic implications for the GCC in particular, but also for the wider region?

\section{REFERENCES}

Acemoglu, Daron (2008). "Oligarchic vs. Democratic Societies." Journal of the European Economic Association 6.1: 1-44.

Ali, Omer and Ibrahim Elbadawi (2012). "The Political Economy of Public Sector Employment in Resource Dependent Countries," ERF Working Paper \# 673, the Economic Research Forum, Cairo, Egypt.

Arezki, Rabah and Akito Matsumoto (2018). Shifting Commodity Markets in a Globalized World. (Editors). International Monetary Fund, Washington DC, USA. 
Bodea, C. and I. Elbadawi (2007). "Riots, coups and Civil War: Revisiting the Greed and Grievance Debate," World Bank Policy Research Working Paper 4397, Washington, DC.

Caselli, F. and W. J. Coleman II (2013). "On the Theory of Ethnic Conflict," Journal of the European Economic Association, 11(Supplement 1): 161-92.

Cingranelli, David L. and Richards, David L. (2008). Cingranelli-Richards (CIRI) Human Rights Dataset 2008 (Available from www.humanrightsdata.org).

Collier, P. and B. Goderis (2009). "Commodity prices, growth and the natural resource curse: reconciling a conundrum," CSAE Working Paper Series 2007-15, Centre for the Study of African Economies, University of Oxford.

Collier, P. and A. Hoeffler (2004). "Greed and Grievance in Civil War," Oxford Economic Papers 56: 563-95.

Desai, Raj M., Olofsgård, A. and Yousef, T. (2009). "The Logic of Authoritarian Bargains," Economics \& Politics, 21:1, pp. 93-125.

Elbadawi, Ibrahim (2016). "Thresholds Matters: Resource Abundance, development and Democratic Transitions in the Arab World," in Ishac Diwan and Ahmed Galal (editors). The Middle East in Times of Transitions. Palgrave Macmillan.

Elbadawi, Ibrahim and Makdisi, Samir, ed. (2011). Democracy in the Arab World: Explaining the Deficit. Routledge.

Elbadawi, Ibrahim and Makdisi, Samir (2013). "Deconstructing Democratic Transitions in the Arab World," unpublished mimeo, Institute of Financial Economics, Department of Economics, The University of Beirut, Beirut, Lebanon.

Elbadawi, Ibrahim and Makdisi, Samir, ed. (2017). Democratic Transitions in the Arab World. Cambridge University Press.

Elbadawi, Ibrahim and Raimundo Soto (2012a). "Economic Growth During the Oil Cycle," ERF Working Paper \# 678, the Economic Research Forum, Cairo, Egypt.

Elbadawi, Ibrahim and Raimundo Soto (2012b). "Sources of Economic Growth and Development Strategy in Dubai," in Ibrahim Elbadawi and Ali Alsadik (editors). The Global Economic Crisis and Implications for Dubai Strategy for Economic Development. Palgrave Macmillan.

Elbadawi, Ibrahim and Raimundo Soto (2015). "Resource Rents, Institutions and Violent Civil Conflicts," Defense and Peace Economics, 2015, vol. 26, issue 1: pp. 89-113.

Elbadawi, Ibrahim, Makdisi, Samir and Milante, Gary (2011). "Explaining the Arab Democracy Deficit," in Elbadawi and Makdisi (ed.), Democracy in the Arab World: Explaining the Deficit, Routledge, pp. 41-82.

Elbadawi, Ibrahim, Mohamed Goaid, Moez Ben Taher (2017). "Threshold Effects of FiscMonetary Interdependence and Exchange Rate Regimes in Oildependent Arab Economies," unpublished mimeo, the Economic Research Forum, Cairo, Egypt. 
Esfahani, Hadi and Esra Ceviker Gurakar (2014). "Social Order, Rents, And Economic Development in Iran Since Early 20th Century," ERF Working Paper \# 850, the Economic Research Forum, Cairo, Egypt.

Fearon, J. D. (2005). "Primary Commodity Exports and Civil War," Journal of Conflict Resolution 49: 483-507.

Henisz, W. and B. A. Zelner (2010). Measures of Political Risk Database, The McDonough School of Business, Georgetown University: http://www-management.wharton.upenn.edu/henisz/.

Hodler, R. (2006). "The curse of natural resources in fractionalized countries," European Economic Review 50: 1367-86.

Miguel, E., S. Satyanath, and E. Sergenti (2004). "Shocks and Civil Conflict: An Instrumental Variable Approach," Journal of Political Economy, 112(4),725-53.

North, Douglass C., John J. Wallis, and Barry R. Weingast (2009). Violence and Social Orders: A Conceptual Framework for Interpreting Recorded Human History. Cambridge: Cambridge University Press.

Robinson, J. A., R. Torvik and T. Verdier (2006). "Political Foundations of the Resource Curse." Journal of Development Economics 79, 447-68.

Ross, M. (2009). "Oil and Democracy Revisited," unpublished mimeo, UCLA Department of Political Science Los Angeles, CA 90095, March.

Ross, M. (2004). "What Do We Know About Natural Resources and Civil War?," Journal of Peace Research 41: 337-56.

Sambanis, N. (2004). "What Is Civil War. Conceptual and Empirical Complexities of an Operational Definition," Journal of Conflict Resolution, 48(6): 814-58.

Soto, Raimundo and Ilham Haouas (2012). "Has the UAE Escaped the Oil Curse?," ERF Working Paper \# 728, the Economic Research Forum, Cairo, Egypt. 
Open Access This chapter is licensed under the terms of the Creative Commons Attribution-NonCommercial-NoDerivatives 4.0 International License (http:// creativecommons.org/licenses/by-nc-nd/4.0/), which permits any noncommercial use, sharing, distribution and reproduction in any medium or format, as long as you give appropriate credit to the original author(s) and the source, provide a link to the Creative Commons licence and indicate if you modified the licensed material. You do not have permission under this license to share adapted material derived from this chapter or parts of it.

The images or other third party material in this chapter are included in the chapter's Creative Commons licence, unless indicated otherwise in a credit line to the material. If material is not included in the chapter's Creative Commons licence and your intended use is not permitted by statutory regulation or exceeds the permitted use, you will need to obtain permission directly from the copyright holder. 